\title{
Incorporating Descriptive Metadata into Seismic Source Zone Models for Seismic-Hazard Assessment: A Case Study of the Azores-West Iberian Region
}

\author{
by Susana P. Vilanova, Eliza S. Nemser, Glenda M. Besana-Ostman, Mourad Bezzeghoud, José \\ F. Borges, António Brum da Silveira, João Cabral, João Carvalho, Pedro P. Cunha, Ruben P. \\ Dias, José Madeira, Fernando C. Lopes, Carlos S. Oliveira, Hector Perea, Julián García- \\ Mayordomo, Ivan Wong, Ronald Arvidsson, ${ }^{*}$ and Joao F. B. D. Fonseca
}

\begin{abstract}
In probabilistic seismic-hazard analysis (PSHA), seismic source zone (SSZ) models are widely used to account for the contribution to the hazard from earthquakes not directly correlated with geological structures. Notwithstanding the impact of SSZ models in PSHA, the theoretical framework underlying SSZ models and the criteria used to delineate the SSZs are seldom explicitly stated and suitably documented. In this paper, we propose a methodological framework to develop and document SSZ models, which includes (1) an assessment of the appropriate scale and degree of stationarity, (2) an assessment of seismicity catalog completeness-related issues, and (3) an evaluation and credibility ranking of physical criteria used to delineate the boundaries of the SSZs. We also emphasize the need for SSZ models to be supported by a comprehensive set of metadata documenting both the unique characteristics of each SSZ and the criteria used to delineate its boundaries. This procedure ensures that the uncertainties in the model can be properly addressed in the PSHA and that the model can be easily updated whenever new data are available. The proposed methodology is illustrated using the SSZ model developed for the Azores-West Iberian region in the context of the Seismic Hazard Harmonization in Europe project (project SHARE) and some of the most relevant SSZs are discussed in detail.
\end{abstract}

Online Material: Tables describing characteristics and boundaries of the seismic source zones.

\section{Introduction}

Since the development of the probabilistic seismichazard analysis (PSHA) formalism (Cornell, 1968), the concept of seismic source zones (SSZs) has been an important component of PSHA. Reiter (1991) distinguishes among three types of seismic sources: faults, localizing structures, and seismotectonic provinces or SSZs. Although faults and localizing structures are identified geological structures that produce earthquakes, SSZs are regions where the lack of correlation between earthquakes and known geological structures prevents the definition of faults or localizing structures. Therefore, SSZs are used in PSHA to address the hazard from earthquakes that are not associated with known geological structures.

\footnotetext{
*Now at Geological Survey of Sweden, Skolgatan 11, S-93070 Malå,
} Sweden.
SSZs are defined by Reiter (1991) as geographic regions that are delineated on the basis of geological, geophysical, and/or seismological similarities. In practice, SSZs are geographic polygons (or volumes, if depth is considered a parameter) that delineate areas with relatively uniform seismicity characteristics. Within an SSZ, the maximum magnitude, depth distribution, style of faulting, rupture orientations, and activity rates at different earthquake magnitudes are assumed to be uniform (although some variability in the activity rates can be allowed, depending on the methodology).

The widely implemented guidelines for PSHA published by the Senior Seismic Hazard Analysis Committee (SSHAC, 1997) include a detailed discussion of SSZs. The report distinguishes among three types of SSZs: (1) area sources that encompass spatial clusters of seismicity, (2) regional area sources, and (3) background area sources. The main difference between a regional and a background source zone is the 

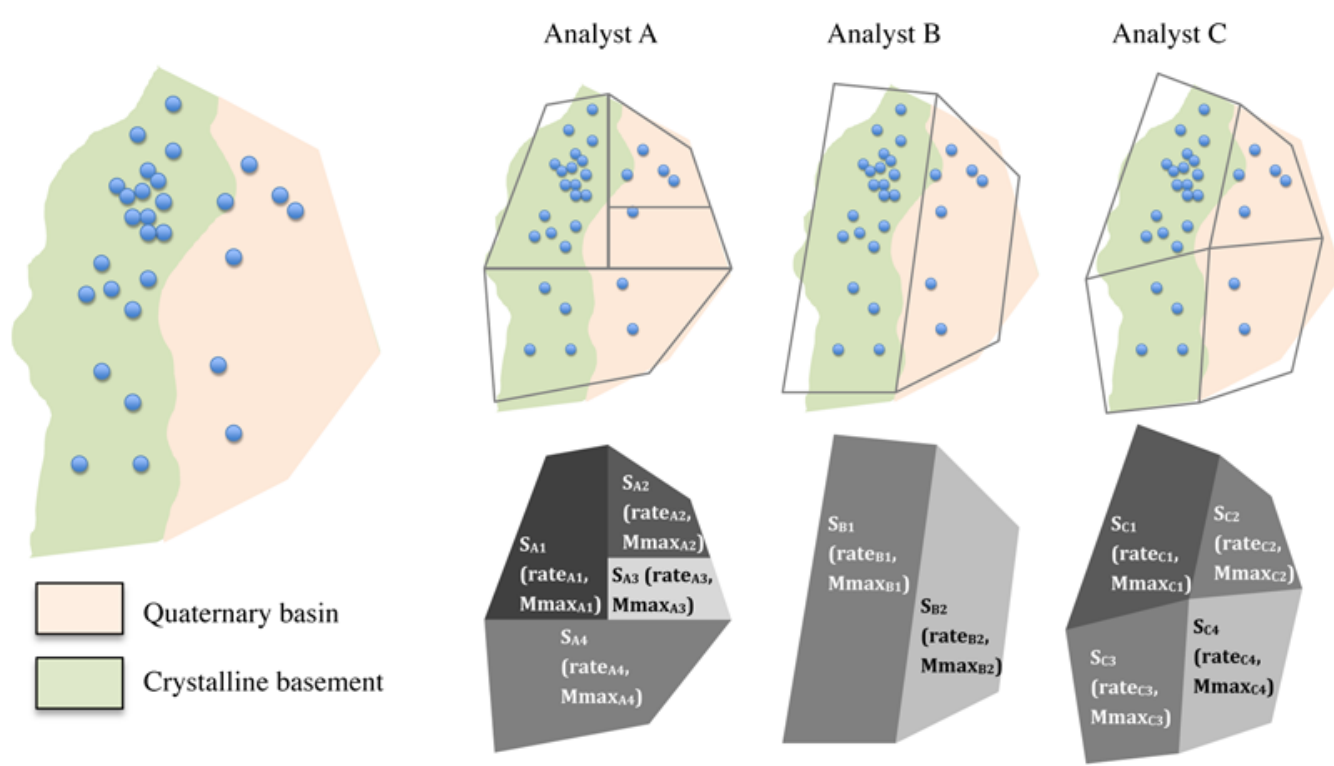

Figure 1. Examples of seismic source zone (SSZ) models outlined for a hypothetical region using different design criteria. On the left, the catalog epicenters (circles) are shown together with the geological provinces. On the right, three different SSZ models are represented: analyst A relied heavily on the seismicity catalog; analyst B assumed the geology to be a better indicator of future seismic behavior, allowing for nonstationarity and/or catalog incompleteness; and analyst $\mathrm{C}$ took an intermediate approach. On the bottom, darker shades of gray represent higher rates of the implicit future seismicity. The color version of this figure is available only in the electronic edition.

scale (tens of kilometers for regional area sources; hundreds of kilometers for background area sources). SSHAC (1997) also highlights the fact that both regional and background area sources are simplified representations of one or more seismogenic structures whose location or activity is unknown; these area sources do not necessarily represent physical characteristics of the seismogenic crust.

Several methods have been proposed to circumvent the use of SSZ models, some of which discard the use of zones altogether. These include the smoothed seismicity method (Frankel, 1995) and the kernel method (Woo, 1996). However, a common criticism of these methods is that they rely heavily on the seismicity catalog without considering other sources of information such as tectonic or geological data that may yield insights into long-term seismogenic processes (e.g., Musson and Sargeant, 2007). The timespan of the seismicity catalog is usually very short relative to the return periods of interest for PSHA studies, and therefore may not accurately reflect the long-term pattern of seismicity in an area. Recent kernel smoothing-based formulations (Hiemer et al., 2013; Hiemer et al., unpublished report, 2014, see Data and Resources section) allow for fault data and associated deformation rates to be included in the analysis. These promising methodologies are, however, difficult to apply to intraplate areas for which active faults are poorly characterized and/or large historical earthquakes show lack of correlation with mapped geological structures.

\section{The Impact of Zonation in PSHA}

Hazard computations with SSZs are conducted with a mathematical model of future seismicity characterized by zone-uniform recurrence. The empirical earthquake catalog and the geological and geophysical data pertaining to the region are used by the analyst to choose the scale of the zones, delineate their boundaries, and estimate the activity rates and other seismicity parameters for each SSZ (e.g., maximum magnitude, depth distribution style of faulting, rupture orientation). The analyst is assisted in this process by theoretical criteria-the "scientific hypotheses of causes of earthquakes" of Kulkarni et al. (1984) — that postulate correlations between the available information (e.g., the empirical catalog, the geology and tectonic regime of the study area, etc.) and the characteristics of future seismicity.

The discussion of the impact of zonation on the hazard results is therefore dependent on the likelihood of agreement between the predictions of the mathematical model and the future seismicity. Because the latter is by definition unknown, the likelihood of agreement must be assessed on the basis of the robustness and local relevance of the scientific hypotheses that underlie the design criteria. When a discrete number of alternative criteria can be formulated in a mutually exclusive and collectively exhaustive (MECE) manner, the logic-tree approach (Kulkarni et al., 1984) is suitable to capture the epistemic uncertainty introduced by the zonation in the final hazard results. A vast literature has been produced in the last decade on the requirements for ground-motion prediction equation design to allow a logic-tree treatment of epistemic uncertainty (e.g., Bommer et al., 2005). However, the corresponding requirements for source area design have received much less attention.

Figure 1 depicts, for a hypothetical region, the geological provinces and the epicentral locations of the seismicity catalog. Also shown are three SSZ models proposed by 
different analysts. Analyst A relied heavily on past seismicity to design the zones of uniform future seismicity, assuming the seismicity process is stationary and the catalog is complete. Analyst B assigned less predictive power to the catalog and trusted the geology to be a better indicator. Finally, analyst $\mathrm{C}$ took the intermediate approach, assuming both past seismicity and geological characteristics can be used with similar effectiveness to predict the patterns of future seismicity. Inasmuch as these hypotheses verify the MECE criterion (A, seismicity is a better predictor than geology; B, geology is a better predictor than seismicity; $\mathrm{C}$, seismicity and geology are comparable predictors), the associated epistemic uncertainty can be captured with the logic-tree approach. It falls on the hazard modeler to rank the relative merits of the alternative zonation models and assign weights accordingly.

The discrete set of zonation models resulting from alternative (and ideally MECE) design approaches is by no means exhaustive, because a great deal of subjectivity is inherent in the application of a particular criterion even if the data were (theoretically) perfect. The degree of subjectivity is enhanced by the fact that the available data often carry significant uncertainties. For example, an aborted rift may be deemed relevant for the delineation of an SSZ, but the depth and breadth of the crustal volume affected may be uncertain and a matter of dispute among experts. Another significant source of uncertainty is the location of historical earthquakes, which is usually associated with large errors. An example is the 1755 Lisbon earthquake; Fonseca (2005) pointed out that different epicentral locations proposed in the literature span an area of about $600 \mathrm{~km}$. Instrumental catalog completeness is another uncertain parameter, as a small number of earthquakes in a particular region may be a significant feature or an artifact of instrumental coverage, and different experts may disagree on the actual cause. Some of this uncertainty is inherent to the problem (e.g., geophysical models of deep structures, not accessible for direct inspection, are always nonunique solutions of inverse problems), whereas some uncertainty may be reduced by future studies (e.g., epicentral errors). Therefore, an SSZ model used in a logic tree may be regarded as the central member of a family of possible models, and the calculation of the hazard for each SSZ branch of the logic tree should integrate over this range of models. A possible way of handling this type of uncertainty in SSZs is through the use of fuzzy boundaries, in which the seismicity rates are smoothed using a 2D Gaussian function (Bender, 1986; Perkins, 2001).

Quantifying the uncertainties is essential in PSHA (Hanks et al., 2009). In order to quantify the uncertainty in SSZ design, it is essential that a proposed SSZ model be accompanied by a comprehensive set of metadata pertaining to the data used and the criteria adopted. However, the criteria underlying the SSZ design process and the theoretical framework supporting them are seldom documented in a suitable way (e.g., García-Mayordomo et al., 2004). A notable exception is the recent comprehensive seismic source model developed for the central and eastern United States by
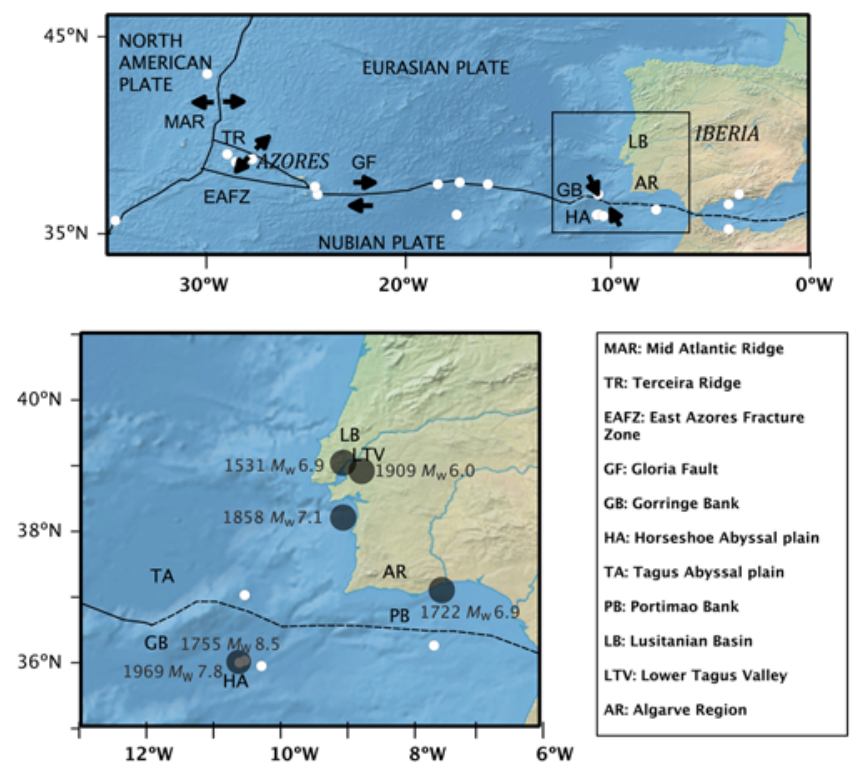

Figure 2. Tectonic setting of the region analyzed and instrumental seismicity (small circles) since $1910\left(M_{\mathrm{w}}, M_{\mathrm{s}}\right.$, or $m_{\mathrm{b}} \geq 6$ ), according to ISC, 2012, see Data and Resources. The large historical earthquakes (large circles) discussed in the text are also indicated. The color version of this figure is available only in the electronic edition.

the Electric Power Research Institute (EPRI), the U.S. Department of Energy (DOE), and the U.S. Nuclear Regulatory Commission (NRC) (EPRI/DOE/NRC, 2012). Furthermore, within an SSZ model, some boundaries may be very well defined by seismicity or geology, whereas others are poorly constrained by the data. In this situation, a proper tracking of the resulting uncertainty requires differentiation between boundaries, an analysis that is rarely conducted. For the case in which the analysis is performed for a single site, as in the case of seismic design of critical structures, not all decisions are equally important; however, for the case of regional hazard maps, all the boundaries are relevant and should be adequately documented.

In this paper, we focus on the development of SSZ models and propose a methodology to select, document, and rate the credibility of each of its component boundaries. This methodology has two goals: (1) to provide third-party researchers or users with a transparent SSZ model so that its limitations are clear and the resulting uncertainties can be addressed and (2) to simplify the process of updating existing SSZ models as new data become available. We illustrate the proposed methodology with the SSZ model developed for the Azores-West Iberia region (Fig. 2) used in the Seismic Hazard Harmonization in Europe project (project SHARE). We also discuss the integration and harmonization of SSZ models at regional and political borders, which is a substantial and ubiquitous challenge that needs to be continually addressed for regional PSHA studies that span political borders. 
Table 1

Degree of Credibility/Usefulness of Data Used to Delineate Area Sources

\begin{tabular}{|c|c|c|c|}
\hline Type of Area Source & Level 1 & Level 2 & Level 3 \\
\hline $\begin{array}{l}\text { Spatial clusters of } \\
\text { seismicity }\end{array}$ & $\begin{array}{l}\text { Well-located instrumental seismicity } \\
\text { and mapped faults in the vicinity of } \\
\text { seismicity. }\end{array}$ & $\begin{array}{l}\text { Historical or poorly located seismicity } \\
\text { and structural features that are } \\
\text { parallel to zones of seismicity. }\end{array}$ & $\begin{array}{l}\text { Focal mechanism and stress } \\
\text { orientation data and rapid lateral } \\
\text { changes in tectonic features. }\end{array}$ \\
\hline Regional area sources & $\begin{array}{l}\text { Changes in the spatial distribution of } \\
\text { seismicity and for regions of } \\
\text { genetically related tectonic history. }\end{array}$ & $\begin{array}{l}\text { Changes in structural styles and } \\
\text { changes in crustal thickness or } \\
\text { composition. }\end{array}$ & $\begin{array}{l}\text { Variations in geophysical signature, } \\
\text { regional stresses, and regional } \\
\text { physiography (surface landforms). }\end{array}$ \\
\hline Background area sources & $\begin{array}{l}\text { Regional differences in structural } \\
\text { styles, tectonic history, } \\
\text { physiography, and geology. }\end{array}$ & & Changes in the character of seismicity. \\
\hline
\end{tabular}

Level 1, high; level 3, low; adapted from SSHAC (1997).

\section{Steps for Developing Consistent and Documented SSZ Models}

Assessment of the Scale and the Degree of Stationarity

We propose the first step toward the development of a consistent and well-documented SSZ model is to decide the appropriate scale. Two conflicting criteria apply: (1) zones should be large enough to encompass sufficient seismicity in order to estimate recurrence and (2) zones should be small enough to represent regions of uniform seismicity. Before considering a small region displaying a cluster of activity as a separate zone, the stationarity of that pattern needs to be established. Seismicity-based design of SSZs has an implicit assumption of stationarity of the seismic activity: future earthquakes are expected to mimic the pattern of the existing catalog (e.g., Kafka, 2002). A lack of stationarity or completeness may preclude the use of the catalog to guide the zonation, in which case geological criteria might perform better. Designing SSZs based on geological data distributes the concentrations of seismicity, providing a way to account for possible long-term nonstationarity (e.g., Frankel et al., 1996; Wong and Olig, 1998). Wong and Olig (1998) emphasize that a combination of the two approaches is the best way to incorporate uncertainty regarding stationarity, pointing out that the degree to which nonstationarity is considered in the modeling should be region dependent. Areas with persistent historical activity are good candidates for stationary behavior. In areas without previously recorded seismicity that display activity in the present, clearly either nonstationary seismogenic processes are at play or the catalog is not representative (e.g., Swafford and Stein, 2007). The assessment of stationarity will heavily rely on the completeness of the seismicity catalog because the spatial distribution of earthquakes depends on the spatially variable detection threshold.

\section{Assessment of Catalog Completeness}

Several characteristics of the analyzed region affect the detection threshold and consequently the earthquake catalog completeness. These characteristics must be taken into account when delineating a zonation model (e.g., Frankel,
1995). For the instrumental record, catalog completeness is a time-varying function of network coverage (Schorlemmer and Woessner, 2008). For the historical record, catalog completeness is affected by the degree of human occupation (e.g., natural boundaries between inhabited and uninhabited regions like offshore areas or deserts), civilizational characteristics (how comprehensive and reliable is the historical record), and sociopolitical history (e.g., regions affected by long wars or invasions).

\section{Assessment and Ranking of Physical Criteria}

The listing of physical criteria considered relevant to delineate SSZs and their relative ranking in terms of importance is the main step in the development of a documented SSZ model. SSHAC (1997) provides a comprehensive list of the types of data used in the definition of area sources and ranks these data types according to their degree of usefulness and credibility for the development of different types of area sources. This ranking scheme is summarized in Table 1. Although the data-type ranking certainly implies some degree of subjectivity, a transparent and clear classification process ensures there will be consistency in the treatment of similar characteristics in a regional sense. A good example of the application of such data-ranking approach is the development of an SSZ model for Switzerland in the context of SSHAC level-4 study PEGASOS (Wiemer et al., 2009).

\section{Documentation of the SSZ Metadata}

In the process of developing an SSZ model, we highlight the importance of producing documentation tables of descriptive metadata that (1) define the unique characteristics of each individual SSZ and (2) systematically detail the criteria for every boundary that separates distinct SSZs. Shells of both types of tables with examples of the recommended data are provided in Tables 2 and 3. These examples are nonexhaustive because the header rows of the documentation tables will depend on the available data for the region under study. 

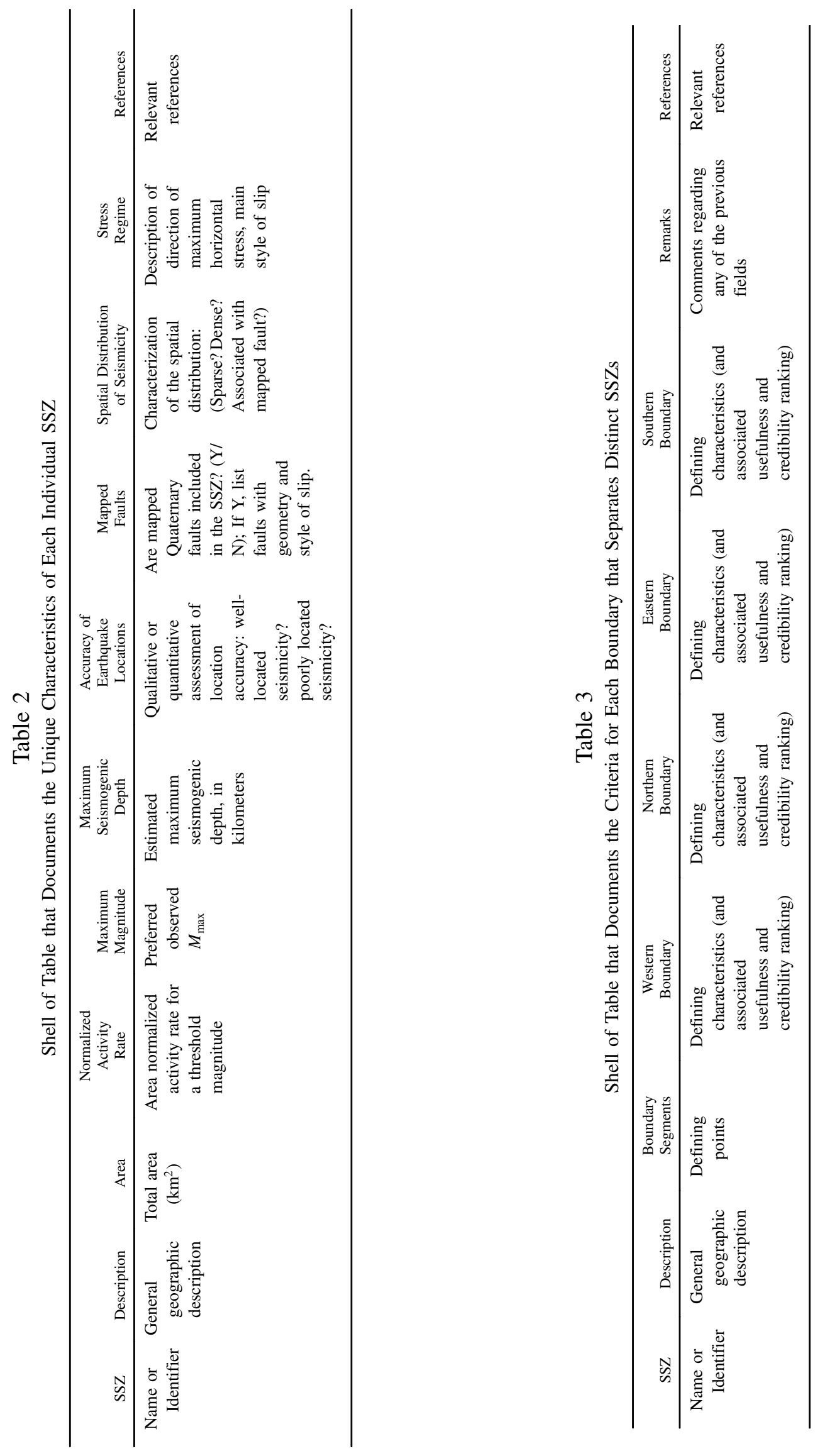
Table 4

Participants and Respective Roles in the Development of the SSZ Model from Azores to Western Iberia

\begin{tabular}{|c|c|c|}
\hline Tasks & Researchers Involved & Institution \\
\hline \multirow[t]{2}{*}{ Methodological definition } & S. P. Vilanova & CERENA, Instituto Superior Técnico, Lisbon, Portugal \\
\hline & E. Nemser & Seismic Hazard Group, URS Corporation, Oakland, California \\
\hline \multirow[t]{3}{*}{ Technical integrators } & S. P. Vilanova & CERENA, Instituto Superior Técnico, Lisbon, Portugal \\
\hline & E. Nemser & Seismic Hazard Group, URS Corporation, Oakland, California \\
\hline & R. Arvidsson & GFZ, German Research Center for Geosciences, Potsdam, Germany \\
\hline \multirow{14}{*}{ Regional experts } & G. M. Besana-Ostman & CERENA, Instituto Superior Técnico, Lisbon, Portugal \\
\hline & M. Bezzeghoud & DF \& CGE, Escola de Ciências e Tecnologia, Universidade de Évora, Évora, Portugal \\
\hline & J. F. Borges & DF \& CGE, Escola de Ciências e Tecnologia, Universidade de Évora, Évora, Portugal \\
\hline & A. Brum da Silveira & DG Faculdade Ciências Universidade de Lisboa/IDL, Lisboa, Portugal \\
\hline & J. Cabral & DG Faculdade Ciências Universidade de Lisboa/IDL, Lisboa, Portugal \\
\hline & J. Carvalho & Laboratório Nacional de Energia e Geologia, Lisboa, Portugal \\
\hline & P. P. Cunha & DCT IMAR-CMA, Universidade de Coimbra, Coimbra, Portugal \\
\hline & R. P. Dias & Laboratório Nacional de Energia e Geologia, Lisboa, Portugal \\
\hline & J. F. D. B. Fonseca & CERENA, Instituto Superior Técnico, Lisbon, Portugal \\
\hline & J. Madeira & DG Faculdade Ciências Universidade de Lisboa/IDL, Lisboa, Portugal \\
\hline & F. C. Lopes & CG, Department of Earth Sciences, University of Coimbra, Coimbra, Portugal \\
\hline & C. S. Oliveira & ICIST, Instituto Superior Técnico, Lisbon, Portugal \\
\hline & H. Perea & DG Faculdade Ciências Universidade de Lisboa/IDL, Lisboa, Portugal \\
\hline & S. P. Vilanova & CERENA, Instituto Superior Técnico, Lisbon, Portugal \\
\hline Regional expert (border integration) & J. García-Mayordomo & Instituto Geológico y Minero de España, Madrid, Spain \\
\hline \multirow[t]{3}{*}{ External panel } & K. Atakan & University of Bergen \\
\hline & P. Villamor & GNS, New Zealand; Seismic Hazard Group \\
\hline & I. Wong & Seismic Hazard Group, URS Corporation, Oakland, California \\
\hline SHARE-SSZ coordinator & R. Arvidsson & GFZ, German Research Center for Geosciences, Potsdam, Germany \\
\hline SHARE-Iberia coordinator & J. Fonseca & CERENA, Instituto Superior Técnico, Lisbon, Portugal \\
\hline
\end{tabular}

\section{Integration and Harmonization across Political Borders}

In cases where the region of interest spans a political border, there are additional considerations to take into account the development of a zonation model. These include (1) the challenge of reconciling existing published (or unpublished) SSZs; (2) the use of different datasets as input (e.g., different seismicity catalogs or the same catalog filtered according to different parameters); (3) the implementation of different methodologies; (4) the adherence to different criteria for ranking the utility of various inputs; (5) the tendency of individual analysts to define larger versus smaller zones; and (6) the consideration of differing levels of consensus for the geometry of particularly complex zones (perhaps as a result of the inclusion of more interpretations).

\section{Application to the SHARE Regional SSZ Model for the Azores-West Iberia}

\section{Project SHARE and the SHARE-Iberia Workgroup}

Project SHARE was funded by the 7th Framework Program of the European Commission and aimed at evaluating the seismic hazards over the European region using a community-based harmonized approach. To accomplish its objectives, the European region and surroundings were divided into seven regions. Project SHARE aimed to follow guidelines of an SSHAC level-3 study, wherein the coordinators promote peer debate and interaction by gathering to- gether a representative group of resource experts in a workshop setting. However, the SSHAC level-3 guidelines were not fully adhered to for time and budget limitations. The workshops to promote expert elicitation and feedback were followed in general, but the expert panel was not a formal Participative Peer Review Panel as preconized by United States Nuclear Regulatory Commision (USNRC, 2012).

Instituto Superior Técnico (Lisbon) was tasked with the integration of data from the Azores and Iberia. For this purpose, a first regional SHARE-Iberia workshop on seismogenic sources was organized in January 2010 in the Algarve (Portugal). Although the main goal of the workshop was to populate the regional active fault database to be used in project SHARE's seismic source model (García-Mayordomo et al., 2012; Nemser et al., 2012; see Basili et al., 2012 and Giardini et al., 2013 in Data and Resources section), the need to develop a continuous, border-consistent SSZ model for the European region provided an opportunity to discuss different zonation practices in general and different zonation models for Western Iberia and the Azores in particular. Approximately 40 resource experts in the fields of seismology, geology, and seismic hazards attended this workshop.

At the workshop, a first draft SSZ model was developed. This model was refined in subsequent meetings (e.g., the First Iberian Meeting on Active Faults and Paleoseismology, Iberfault, meeting held in Sigüenza, Spain, in 2010) and revised to incorporate several rounds of feedback from the regional and external experts. The documentation tables (Tables 2 and 3) were created in this context by the integrators 
to promote and facilitate the discussions and interaction between experts and proved to be critical tools in the achievement and documentation of a consensus model. The final model and corresponding documentation were delivered to project SHARE in November 2010 and revised by the hazard modeling team. Table 4 lists the participants and respective roles in the development of the Azores-West Iberia SSZ model presented in this paper.

\section{Regional Tectonic, Geological, and Geographic} settings

The analyzed region, shown in Figure 2, comprises different tectonic regimes and lithospheric rheologies. The westernmost portion, the Azores Archipelago, located in the Atlantic Ocean, is characterized by active transtensional tectonics related to the Azores Triple Junction, which separates the North American, Eurasian, and Nubian tectonic plates. The triple junction is formed by the intersection of the midAtlantic ridge that runs roughly north-south and the westnorthwest-east-southeast-striking Terceira ridge. The Azores islands are located within a volcanic plateau delimited to the northeast by the Terceira ridge, to the south by the East Azores Fracture Zone, and to the west by the mid-Atlantic ridge (e.g., Lourenço et al., 1998). Further east, the Terceira Rift joins the western limit of the Gloria dextral transform fault, which marks the border between the Eurasian and Nubian lithospheric plates up to the longitude of around $13^{\circ} \mathrm{W}$ (e.g., Buforn et al., 1988). To the east of this meridian, the plate boundary becomes diffuse and the lithosphere exhibits a complex transition from oceanic to continental (e.g., González-Fernandez et al., 2001; Rovere et al., 2004). This region is dominated by transpressional tectonics and characterized by complex bathymetry, with high sea mountains such as the Gorringe bank intercalated with deep abyssal plains such as the Horseshoe or Tagus abyssal plains.

The instrumental seismicity broadly defines the plate boundary and the convergent velocity between Nubia and Iberia is around $5 \mathrm{~mm} /$ year (e.g., Fernandes et al., 2003). The largest known earthquake to occur at or near the plate boundary in this region was the 1755 Lisbon earthquake with an estimated moment magnitude $\left(M_{\mathrm{w}}\right)$ 8.5-8.7 (Johnston, 1996b; Martínez Solares and López Arroyo, 2004). The Eurasian plate within the study region includes a large extension of oceanic lithosphere to the west, which is gradually replaced by transitional lithosphere and then by continental lithosphere. Because of Mesozoic rifting that led to the opening of the Atlantic Ocean, part of the lithosphere in Western Iberia was extended and thinned (Wilson, 1975) and is currently overlain by thick Mesozoic and Cenozoic sediments. These basins are located on top of a densely fractured basement accreted during the Paleozoic, known as the Hesperic Massif (Ribeiro et al., 1979). This intraplate region located north of the diffuse plate boundary is characterized by low seismicity and deformation rates (fault slip rates $<1 \mathrm{~mm} / \mathrm{yr}$ ), but it has experienced several $M_{\mathrm{w}} \sim 7$ earth- quakes both in historical (e.g., Vilanova and Fonseca, 2007) and in prehistorical (Rockwell et al., 2009) times.

Development of the SSZ Model for the Azores-West Iberia Region

Assessment of the Scale and the Degree of Stationarity. The logic-tree design for the SHARE project includes three branches: (1) an area source model, which assumes uniform distribution of seismicity in time and space within each zone (Woessner et al., unpublished report, 2014; see Data and Resources); (2) a kernel-smoothed model that generates forecasts based on gridded-smoothed seismicity and on fault-based seismic-moment release (Hiemer et al., 2013; Hiemer et al., unpublished report, 2014; see Data and Resources); and (3) a model that determines activity rates based on slip rates of active faults embedded in background seismicity zones (here, "background" has a different definition than that of SSHAC, 1997; Woessner et al., unpublished report, 2014; see Data and Resources). Because background sources will not be used alone, the potential nonstationarity of seismicity or the limitations of the historical seismicity record need to be taken into account either by using a relatively large correlation distance in the smoothed-seismicity models or by using relatively large SSZs in the regional SSZ models. In view of these considerations, it was decided that the regional source areas (tens-ofkilometer length scales) defined by SSHAC (1997) were the most suitable for the project's requirements.

The development of harmonized open-access catalogs across Europe was a major undertaking in project SHARE (Grünthal and Wahlstrom, 2012; Stucchi et al., 2012; Giardini et al., 2013). However, the chosen minimum threshold of $M_{\mathrm{w}} 4.0$ of project SHARE working catalogs is too high to address the spatial patterns of seismicity within the intraplate region. This limitation of the catalog was related to the difficulties inherently associated with harmonizing data from different countries within the time frame and budget available. Therefore, we based our assessment on the regional seismic catalog of Carrilho et al. (2004). The historical seismicity record is taken from Vilanova and Fonseca (2007), who calculate $M_{\mathrm{w}}$ for historical earthquakes based on Johnston (1996a) correlations for stable continental regions. Later on we discuss the differences between the historical earthquake parameterization of Vilanova and Fonseca (2007) and that of Stucchi et al. (2012).

Figure 2 shows that the instrumental seismicity with surface-wave magnitude $\left(M_{\mathrm{s}}\right)$, body-wave magnitude $\left(m_{\mathrm{b}}\right)$, or $M_{\mathrm{w}}>6.0$ broadly defines the position of the plate boundaries but provides little insight into hazard-relevant seismicity that affects the plate interior. In Figure 3, the catalog of Carrilho et al. (2004) updated according to Instituto Português do Mar e Atmosfera (IPMA, unpublished report, 2012; see Data and Resources) is used to address the issue of the degree of stationarity. Carrilho et al. (2004) use a local magnitude scale $\left(M_{\mathrm{L}}\right)$ based on the definition of the Richter standard seismic event (an $M_{\mathrm{L}} 3.0$ earthquake is defined as 

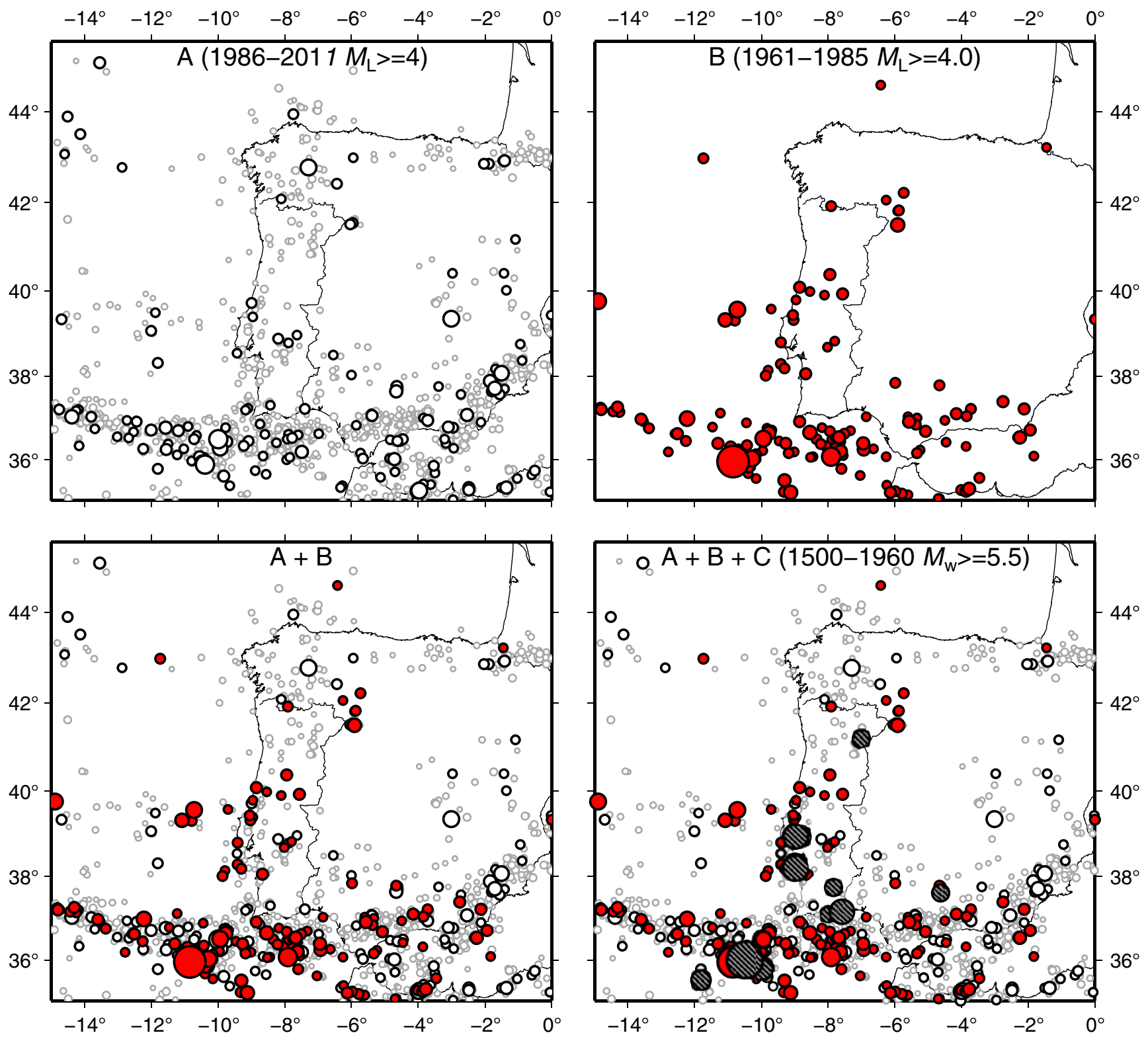

Figure 3. Instrumental seismicity catalog (Carrilho et al., 2004, updated according to IPMA, unpublished report, 2012; see Data and Resources), plotted for two consecutive 25 -year time periods. Subset A is represented by white circles (outlined in gray for $3 \leq M_{\mathrm{L}} \leq 4$ ), and subset B is represented by solid-filled circles. Both subsets are fairly complete above the $M_{\mathrm{L}}$ threshold chosen for each period. Subset C (represented by striped-filled circles) corresponds to the historical seismicity record with $M_{\mathrm{w}} \geq 5.5$ according to Vilanova and Fonseca (2007). The seismicity catalog was declustered using the Reasenberg (1985) algorithm. The color version of this figure is available only in the electronic edition.

having a maximum displacement of $1 \mathrm{~mm}$ on simulated Wood-Anderson seismograph at a distance of $100 \mathrm{~km}$ from the epicenter) when possible. If not, they use $M_{\mathrm{L}}$ equivalent values based on correlations with either duration or other magnitude scales. Figure 4 presents the catalog completeness analysis performed with the Stepp (1972) methodology, which is based on the assumption that the earthquake distribution is Poissonian. Under this premise the process is fully described by the mean occurrence rate $\lambda$, the variance of which is given by $\sigma^{2}=\lambda / \Delta T$ ( $\Delta T$ is the observational period). The completeness interval is estimated by visually identifying on a $\log -\log$ plot the departure of the data's $\sigma$ from the expected slope, with increasing observational periods. The catalog completeness analysis indicates the catalog is complete for $M_{\mathrm{L}} \geq 3.0$ for the period 1986-2011. For lower magnitude thresholds, the completeness period is very short (less than a decade), whereas for $M_{\mathrm{L}} \geq 4.0$, the catalog is complete for its full duration (1961-2011).

A comparison of the seismicity patterns during the periods 1986-2011 (Fig. 3a) and 1961-1985 (Fig. 3b) shows that (1) the diffuse plate boundary is broadly defined by seismicity in both periods and with both magnitude thresholds; (2) the seismicity of the plate interior is persistent for the two periods in some regions (e.g., Lusitanian basin), but seems 

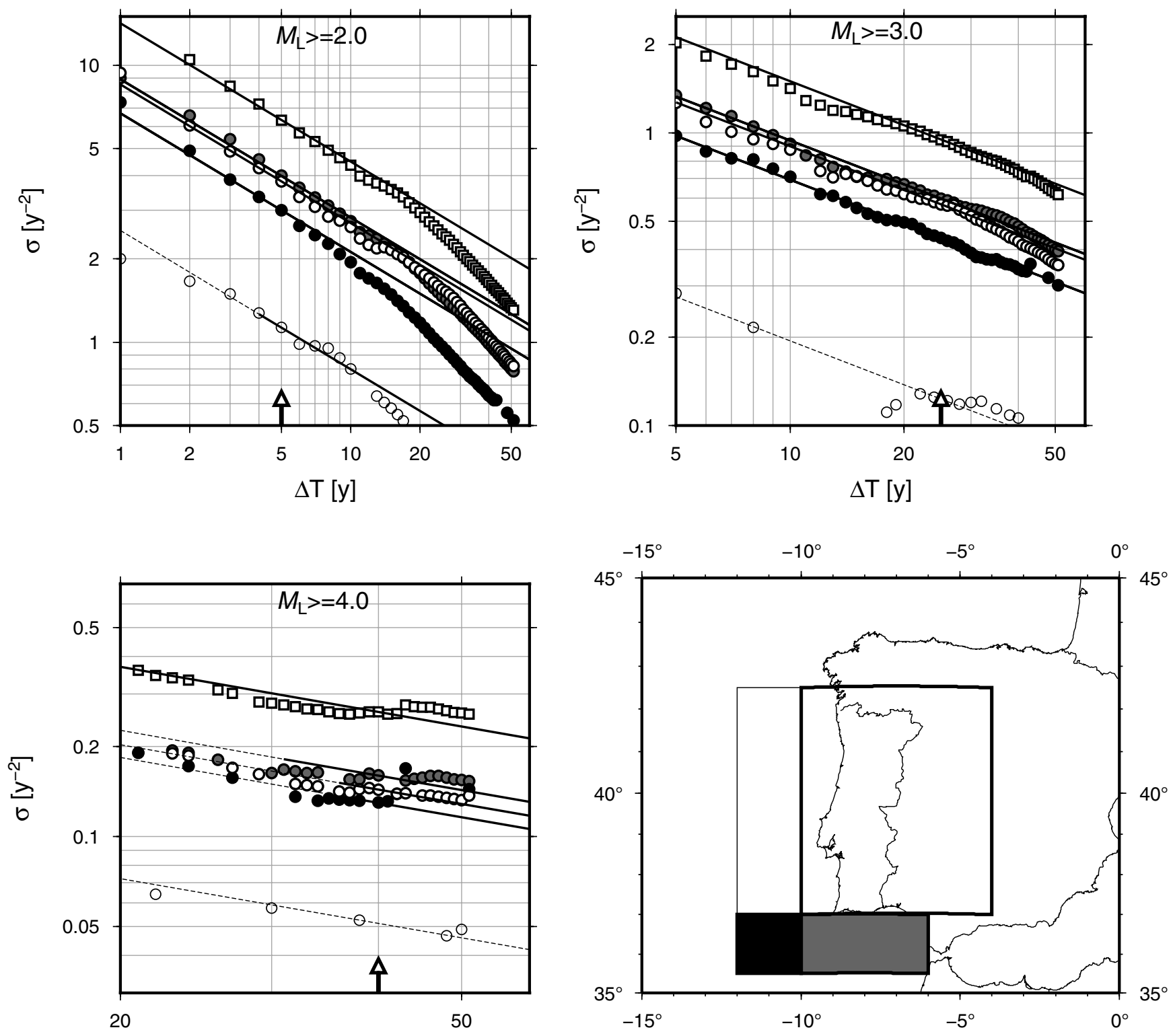

$\Delta \mathrm{T}[\mathrm{y}]$

Figure 4. Completeness analysis performed with the Stepp (1972) method for different magnitude thresholds. Different shades are used for depicting data from the corresponding geographic regions on the map (bottom left). The sum of individual regions is represented by squares. The lines depict the Stepp functions represented for the observational periods $\Delta T$, indicated by arrows. A dashed line is used to indicate that in the corresponding observational period the Stepp function $\sigma$ is not considered statistically robust (number of observations $<25)$. The seismicity catalog was declustered using the Reasenberg (1985) algorithm.

highly variable in others (e.g., central Portugal, around $40^{\circ} \mathrm{N}$ ); and (3) zones affected by damaging historical earthquakes with onshore epicentral areas had no significant seismicity during the 50 years covered by the catalog (historical offshore earthquakes cannot be used in this way because the uncertainties affecting their locations are too large). Although this analysis is clearly nonexhaustive because it is not based on a robust statistical study as that used by Kafka (2002), we conclude that in this study region the seismicity record is a more reliable criterion to delineate SSZs for the plate-boundary regions than for the plate interior.
The seismicity catalog published by the Instituto Geográfico Nacional (IGN) from Spain provides local magnitudes based on correlations with the amplitude of the $L g$ phase $\left(m_{\mathrm{b} L g}\right)$ for post-1967 earthquakes (Martínez Solares and Mezcua, 2002). The same exercise performed over the IGN cata$\log$ shows that the number of earthquakes $m_{\mathrm{b} L g}>3.0$ for the period 1980-2000 is significantly larger (37\% larger for the region between $13^{\circ}-6^{\circ} \mathrm{W}$ and $35.5^{\circ}-42.5^{\circ} \mathrm{N}$ ) than that reported by Carrilho et al. (2004) for the same region and period, indicating some inconsistency among the local magnitude scales used by both institutions. The seismicity pattern for 
Table 5

Criteria for Defining Regional SSZs and their Relative Ranking According to SSHAC (1997)

\begin{tabular}{lll}
\hline \multicolumn{1}{c}{ Criteria } & Ranking & \multicolumn{1}{c}{ Definition } \\
\hline Physical & Level 1 (L1) & $\begin{array}{l}\text { Spatial distribution of } \\
\text { seismicity } \\
\text { Genetically related } \\
\text { tectonic history } \\
\text { Structural styles } \\
\text { Crustal thickness or } \\
\text { composition } \\
\text { Geophysical signature } \\
\text { Regional stresses } \\
\text { Catalog completeness } \\
\text { Regional physiography } \\
\text { Offshore versus onshore }\end{array}$ \\
\hline
\end{tabular}

the previous two decades is also slightly different but the general remarks stated above are still applicable.

Assessment of Factors Affecting the Catalog Completeness. Given the geographic location of the study area (Fig. 2), the coastline is the prevailing criterion guiding the development of SSZs. The fine-tuning of the position of the onshore-offshore detection threshold boundary is based on the completeness analysis of the seismicity catalogs.

Assessment and Ranking of the Physical Criteria. The physical criteria corresponding to the regional area sources and their relative ranking according to SSHAC (1997) are summarized in Table 5. A specific boundary is to be defined with the aim of satisfying the criteria with higher degrees of usefulness and credibility. However, within the intraplate region, the criterion based on the spatial distribution of seismicity is ambiguous because data are sparse. Therefore, within this region, although the boundaries reflect changes in the density or character of seismicity, they are actually outlined using criteria with lower degrees of usefulness and credibility.

Documentation of the Criteria. In this section, we discuss the rationale behind the definition of selected SSZs in the SHARE-West Iberia model, and we present the corresponding documentation tables. Tables 6 and 7 exemplify the documentation tables for three selected SSZs. (E) The full documentation tables for West Iberia are available in the electronic supplement to this article (Tables S1 and S2). For regional location names and the locations of historical earthquakes discussed in the text, refer to Figure 2. Figure 5 illustrates the final SSZ model for the region analyzed and the details of the West Iberia model superimposed on the types of data used for its development.

Throughout the section, we refer to the $M_{\mathrm{w}}$ estimates that were calculated or compiled by Vilanova and Fonseca (2007), unless otherwise stated. Stucchi et al. (2012) recalculated the magnitudes for the European historical earthquake catalog using methodologies based on macroseismic intensity data- points (MDPs). The final $M_{\mathrm{w}}$ estimates of Stucchi et al. (2012) were calculated by a weighted mean, using the values previously published in regional catalogs or dedicated studies with a weight of 0.25 , and the values calculated from MDPs with a weight of 0.75 . However, acknowledging that the calibration methods employed were not very reliable for West Iberia due to the lack of earthquakes $M_{\mathrm{w}}>6.0$ in the calibration dataset, for that region Stucchi et al. (2012) used the same weight for both $M_{\mathrm{w}}$ estimates. The values estimated by Vilanova and Fonseca (2007), which are based on worldwide calibration sets (Johnston, 1996a), are not subject to this limitation and are probably more robust for larger values of $M_{\mathrm{w}}$. In general, the $M_{\mathrm{w}}$ values calculated using MDP-based methodologies are significantly lower than those calculated by Vilanova and Fonseca (2007).

The southern Lusitanian basin (SSZ 6; Fig. 5 and Tables 6 and 7; PTAS266 is the corresponding SHARE identifier in Giardini et al., 2013, see Data and Resources) is a region of continental crust that underwent extension during the opening of the North Atlantic in the Mesozoic. It encompasses the western portion of the Lower Tagus basin, which has been frequently impacted by damaging earthquakes during the historical period. The best-documented earthquakes in this region are the $1531 M_{\mathrm{w}} 6.9$ earthquake, the great 1755 $M_{\mathrm{w}}$ 8.5-8.7 Lisbon earthquake (which may have had a secondary rupture along the Lower Tagus Valley, as proposed by Vilanova et al., 2003), and the 1909 Benavente earthquake (Fonseca and Vilanova, 2010) with estimates of $M_{\mathrm{w}} 6.0-6.2$ based on early instrumental records (Teves-Costa et al., 1999; Stich et al., 2005) (Fig. 2). Present-day instrumental seismicity is almost absent from the region affected by historical damage, suggesting quiescent behavior. Likewise, the region affected by the $1858 M_{\mathrm{w}} 7.1$ Setúbal earthquake, located further southwest within the continental shelf, also displays low instrumental seismicity rates. Several studies have proposed a structural relationship between both regions (e.g., Fonseca and Long, 1991; Vilanova and Fonseca, 2004; Carvalho et al., 2011). A complex system of potentially active faults has been identified within the Lower Tagus Valley using geomorphological analysis, geological outcrop, and geophysical data (e.g., Carvalho et al., 2011; Besana-Ostman et al., 2012). SSZ 6 was defined taking into account the extent of the onshore region (L0 criterion) formed by extended continental crust ( $\mathrm{L} 1$ criterion) that comprises the proposed active faults systems (L2 criterion).

The Algarve region (SSZ 11; Fig. 5 and Tables 6 and 7; PTAS260 is the corresponding SHARE identifier) is located at the southern edge of the stable continental crust, in the vicinity of the Azores-Gibraltar plate boundary, which becomes diffuse as the crust passes from oceanic to continental. It encompasses the southernmost Carboniferous low-grade metamorphic segment of the Hercynian Iberian Massif, which is overlain by a small-scale Mesozoic basin related to the development of the Neo-Tethys Sea (Terrinha, 1998) and a smallscale Cenozoic basin related to the development of the westernmost end of the Alpine mountain belt (e.g., Lopes et al., 


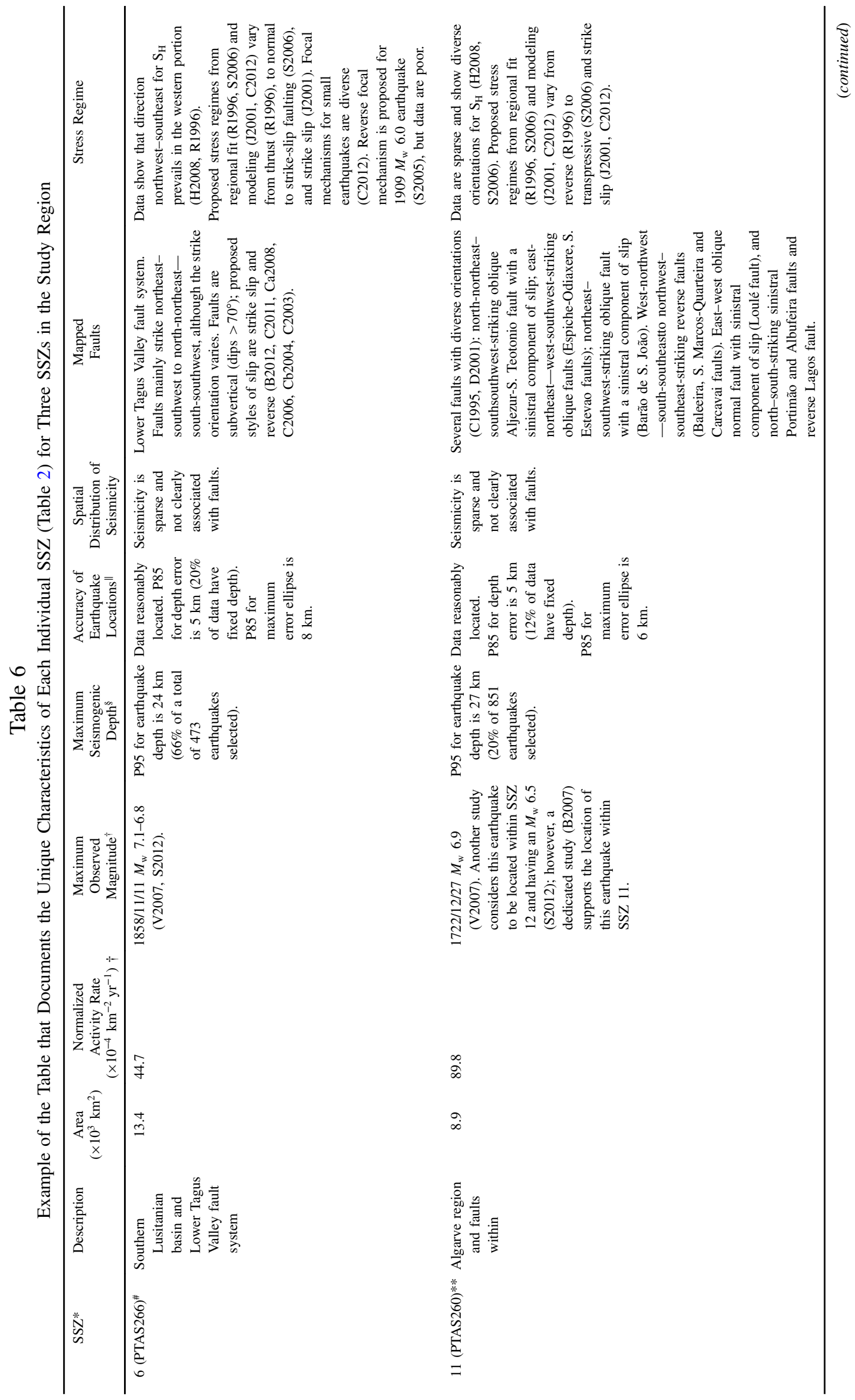




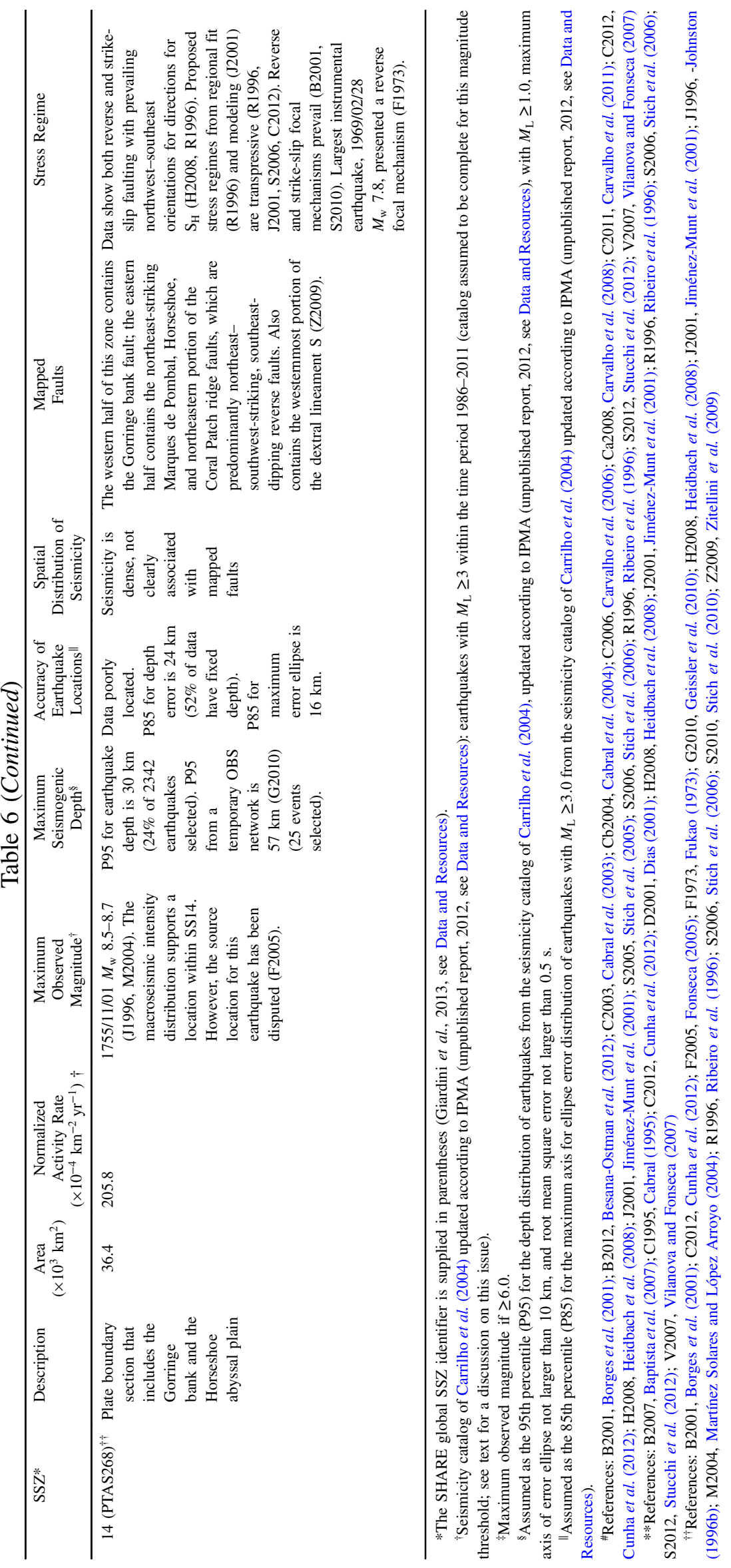




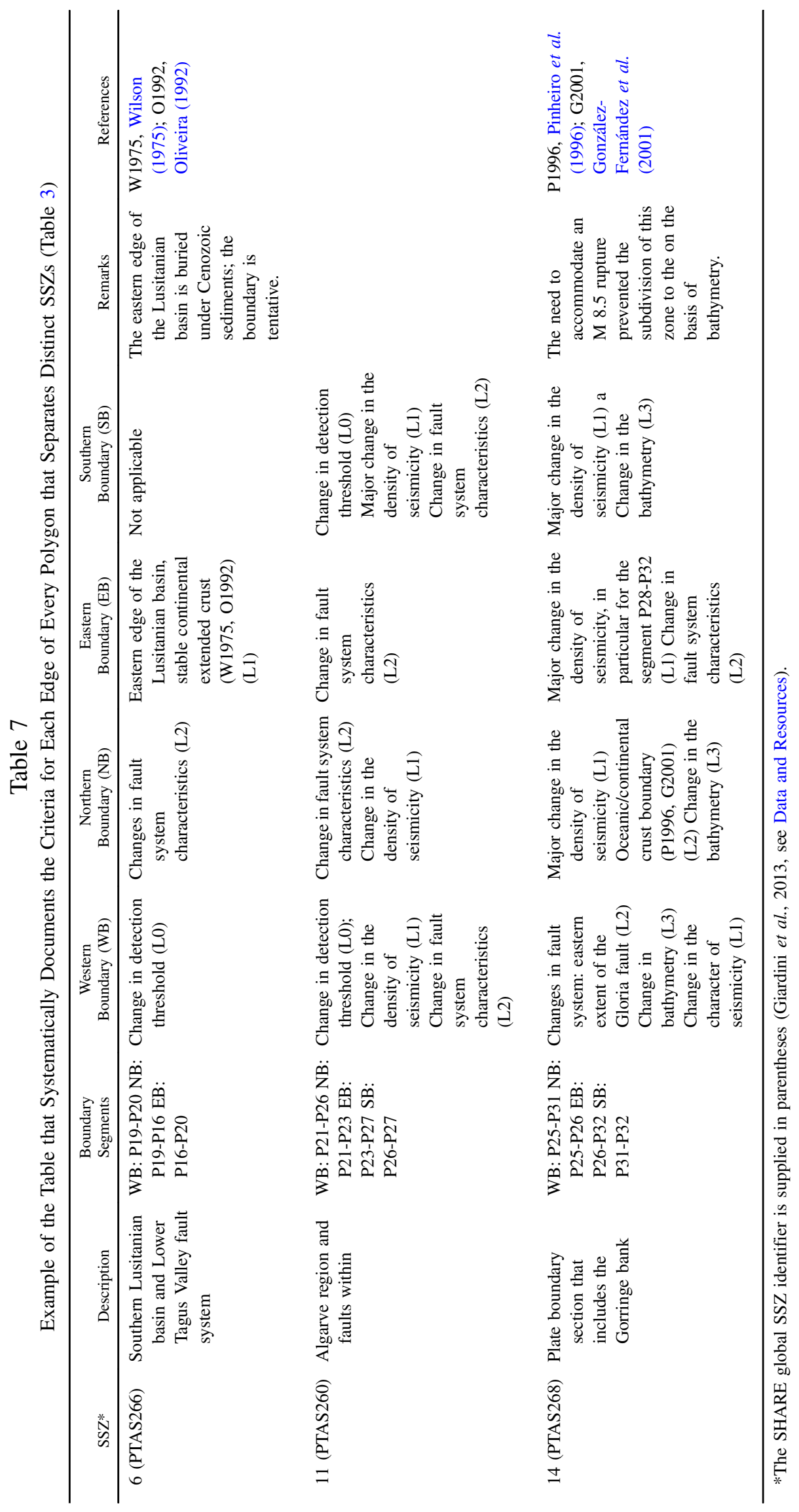



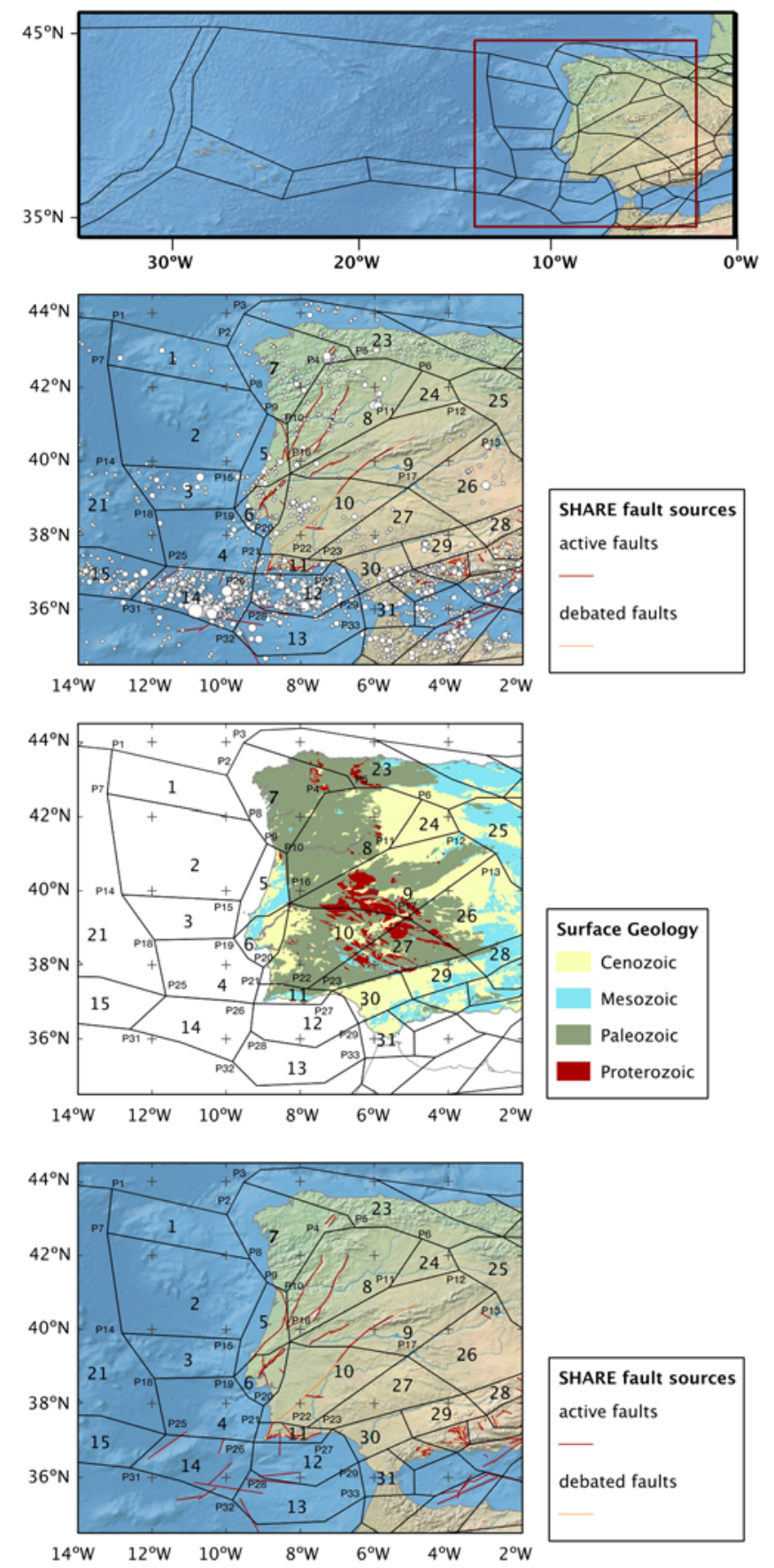

Figure 5. Full SSZ model for the analyzed region and detail of the West Iberia model superimposed on the different types of data considered most relevant for its development. The color version of this figure is available only in the electronic edition.

2006). The region has a history of damaging earthquakes that may be related to the transpressive tectonics of the offshore plate boundary. The $1722 M_{\mathrm{w}} 7.1$ Tavira earthquake is the best-documented damaging event in the Algarve. The dedicated study of Baptista et al. (2007) proposes a geological structure within the continental shelf of the Algarve as the source for the 1722 earthquake, based on tsunami travel-time simulations. Vilanova and Fonseca (2007) calculated a mag- nitude of $M_{\mathrm{w}} 6.9$ for this event, assuming a location within the SSZ 11. On the other hand, Stucchi et al. (2012) assumed an offshore location for this event (within SSZ 12) based on the catalog of Martínez Solares and Mezcua (2002). For the purpose of the SSZ model, we considered the location within SSZ 11. However, a remark was introduced in the table documenting the SSZs, in order to acknowledge the fact that different interpretations exist.

The northern boundary of SSZ 11 was outlined in order to include the set of potentially active faults proposed for the region (L2 criterion), whereas the southern boundary marks the major change in the density of seismicity (L1 criterion) that highlights the transition from stable lithosphere to active lithosphere. The western and eastern boundaries reflect physiographic and geological changes (L3 criteria), respectively.

The Gorringe region (SSZ 14; Fig. 5 and Tables 6 and 7; PTAS268 is the corresponding SHARE identifier) is located to the southwest of the Iberian continental margin within a region of complex transition from oceanic lithosphere to crustal lithosphere (e.g., González-Fernández et al., 2001; Rovere et al., 2004). The region displays a prominent bathymetric feature, the seamount Gorringe bank, which is flanked to the southeast by the Horseshoe abyssal plain. The Gorringe bank is mainly composed of sepentinite, gabbros, and extrusive volcanic rocks and has been interpreted as an uplifted block of oceanic lithosphere (Auzende et al., 1978). This region encompasses the source of the $1969 M_{\mathrm{w}} 7.9$ earthquake (Fukao, 1973) and is also the main candidate for having produced the great 1755 Lisbon earthquake (Grandin et al., 2007). The northern boundary of SSZ 14 is marked by a major change in the density of seismicity ( $\mathrm{L} 1$ criterion) and is also coincident with the oceanic-continental crust boundary as inferred from Pinheiro et al. (1996) and González-Fernández et al. (2001) (L3 criterion). The southern boundary reflects a major change in the density of seismicity (L1 criterion) and substantial changes in physiography (L3 criterion). The western boundary marks both a change in fault system characteristics (eastern extent of the Gloria fault; L2 criterion), bathymetry (L3 criterion), and a change in the character of seismicity (the prevailing stress regime for large magnitude earthquakes changes to the west from reverse to strike slip and larger magnitude seismicity is distributed within a narrow band to the west; L1 criterion). Finally, the eastern boundary is coincident with the western edge of the Gulf of Cadiz accretionary wedge (L2 criterion) and also marks a change in the density of seismicity (L1 criterion), particularly in the southern region. There was debate as to whether or not the SSZ 14 should be subdivided on the basis of a change in the bathymetry. However, because this region is the most likely source of the $1755 M_{\mathrm{w}} 8.5-8.7$ earthquake and accordingly must be able to accommodate rupture lengths longer than $200 \mathrm{~km}$, the zone was not further subdivided.

Integration with the Spanish Model. The Spanish zonation model was created following a level-2 SSHAC methodology. The process was led by the Spanish regional expert acting as 
the technical integrator for Spain (Table 4) and consisted of requesting expert opinions from a group of Spanish geologists following an iterative process of discussion and agreement until a final integrated model was produced (García-Mayordomo et al., 2010). For each main geological region of Spain (Pyrenees, Catalan Coastal Ranges, Iberian Range, Betic Cordillera, the Hesperian Massif), a set of different SSZ models, either selected from the literature or prepared $a d$ hoc based on methodology outlined in García-Mayordomo (2005), were plotted over a number of background maps: a digital terrain model, a geological and tectonic map, a depth of the Moho map, heat flux maps, and seismic catalog maps. The experts from each region were supplied with this information package and requested to select the best model and/or indicate changes to produce a better-performing model. The technical integrator analyzed the feedback, prepared a new model, and sent it back for further discussion. This process was performed iteratively until the technical integrator achieved a final integrated model. The few zones crossing the Spain-Portugal border were discussed with the SHARE-Iberia group. Although the data ranking is different from that used for the West Iberian region, the resulting SSZ models were relatively compatible and only small details required discussion and adjustment to achieve a consistent model. The direction of the eastern boundary of SSZ 8, ultimately decided on the basis of physiographic features, is an example of a modification to the preliminary Spanish model (García-Mayordomo et al., 2010) during this integration process.

\section{Discussion and Conclusions}

SSZ models are widely used as input into PSHA as a means of incorporating information about earthquakes that are not clearly associated with active geological structures. However, the inherent subjectivity of these models is problematic in terms of reproducibility and must be taken into account when quantifying the epistemic uncertainty of the final hazard assessment. Because both the criteria underlying the design of SSZ models and its limitations are rarely explicit, attempts to update existing SSZ models in the presence of new data are complicated, and uncertainties in the model may propagate through the process in a way that is not accounted for. The task of developing or improving regionalscale SSZ models may be challenged with the lack of standardization in input datasets, methodologies, criteria for ranking the importance of various inputs, or scale considerations. Some of these issues have prominently been considered within the project SHARE, which provided harmonized open-access datasets across Europe.

The evaluation of the degree of stationarity, the assessment of catalog completeness, the adoption of ranking criterion for inputs (such as the SSHAC, 1997, model), and the production of descriptive metadata provide a pathway for a standardized methodology for model development, with open access to data being a base requirement. In the context of project SHARE, the task of generating an Azores-West
Iberia source zonation model highlighted the need to generate associated metadata and provided a platform to develop a framework for doing so.

\section{Data and Resources}

The main body of data used in this paper comes from published sources listed in the references. The preliminary catalog of Instituto Português do Mar e Atmosfera (IPMA) used to cover the timespan 2000-2012 is available by request. We used the computer code cluster2000x developed by Paul Reasenberg (http://earthquake.usgs.gov/research/software, last accessed July 2013) to decluster the catalog. The figures were plotted both with the Generic Mapping Tools package developed by Paul Wessel and Walter Smith (http://gmt.soest .hawaii.edu, last accessed July 2013), and the QGIS 1.8.0 Geographic information System, Open Source Geospatial Foundation Project (http://qgis.osgeo.org, last accessed July 2013). Shaded Relief data used for plotting purposes were retrieved from the Natural Earth repository (http://www .naturalearthdata.com, last accessed July 2013). The geological vector data used for plotting purposes were retrieved from the OneGeology-Europe geoportal, http://www.onegeologyeurope.org/portal (last accessed July 2013). SHARE data and zonation models are available at www.efehr.org (last accessed March 2014).

References in the process of publication include "A kernel-smoothed stochastic earthquake rate model considering seismicity and fault moment release for Europe," by S. Hiemer, J. Woessner, R. Basili, L. Danciu, D. Giardini, and S. Wiemer and "The 2013 European Seismic Hazard Model-Key Model Components" by J. Woessner, L. Danciu, D. Giardini, H. Crowley, F. Cotton, G. Grünthal, R. Pinho, G. Valensise, R. Arvidsson, R. Basili, S. Hiemer, C. Meletti, R. Musson, A. Rovida, M. Stucchi, and the SHARE consortium.

The following online databases were used: The European Database of Seismogenic Faults (EDSF) compiled in the framework of the project SHARE (cited as Basili et al., 2013; http://diss.rm.ingv.it/share-edsf/; last accessed March 2014); Seismic Hazard Harmonization in Europe (SHARE), Online Data Resource (cited as Giardini et al., 2013; doi: http://dx.doi.org/10.12686/SED-00000001-SHARE; last accessed March 2014); and The International Seismological Centre (ISC) online bulletin is available at http:// www.isc.ac.uk/iscbulletin/search/ (last accessed July 2013).

\section{Acknowledgments}

This work has been mainly funded by project SHARE (FP7-226967) under the European Commission 7th Framework Programme. The Portuguese Foundation for Science and Technology (FCT) partially supported this work through projects FINDER (PTDC/CTE-GIX/113866/2009) and SCENE (PTDC/CTE-GIX/103032/2008). The FCT Excellence Research Project SEICHE (EXCL/GEO-FIQ/0411/2012) currently supports the first author's research contract. We are grateful to Pilar Villamor and Kuvvet Atakan for their input in the SHARE-Iberia workshop on seismogenic sources and to Jochen Woessner for his valuable comments 
on the final version of the manuscript. We would also like to acknowledge Domenico Giardini for the support provided in the framework of project SHARE. Finally, we gratefully acknowledge the contributions of Associate Editor Matt Gerstenberger, Peter Powers, Mark Stirling, and an anonymous reviewer, whose constructive comments helped us to improve the manuscript.

\section{References}

Auzende, J.-M., J.-L. Olivet, J. Charvet, A. Le Lann, X. Le Pichon, J. H. Monteiro, A. Nicolas, and A. Ribeiro (1978). Sampling and observation of oceanic mantle and crust on Gorringe bank, Nature 273, 45-48.

Baptista, M. A., J. M. Miranda, F. C. Lopes, and J. F. Luís (2007). The source of the 1722 Algarve earthquake: Evidence from MCS and tsunami data, J. Seismol. 11, 371-380.

Bender, B. (1986). Modeling source zone boundary uncertainty in seismic hazard analysis, Bull. Seismol. Soc. Am. 76, 329-341.

Besana-Ostman, G., S. P. Vilanova, E. N. Nemser, A. Falcão-Flor, S. Heleno, H. Ferreira, and J. F. D. B. Fonseca (2012). Large Holocene earthquakes in the Lower Tagus Valley fault zone, central Portugal, Seismol. Res. Lett. 83, 67-76.

Bommer, J. J., F. Scherbaum, H. Bungum, F. Cotton, F. Sabetta, and N. A. Abrahamson (2005). On the use of logic trees for ground-motion prediction equations in seismic-hazard analysis, Bull. Seismol. Soc. Am. 95, 377-389.

Borges, J. F., A. J. Fitas, M. Bezzeghoud, and P. T. Costa (2001). Seismotectonics of Portugal and its adjacent Atlantic area, Tectonophysics 331, 373-387.

Buforn, E., A. Udias, and M. Colombas (1988). Seismicity, source mechanisms and tectonics of the Azores-Gibraltar plate boundary, Tectonophysics 152, 89-118.

Cabral, J. (1995). A Neotectónica em Portugal Continental, Instituto Geológico e Mineiro Memoir 31, Lisbon, Portugal.

Cabral, J., C. Moniz, P. Ribeiro, P. Terrinha, and L. Matias (2003). Analysis of seismic reflection data as a tool for the seismotectonic assessment of a low activity intraplate basin-The Lower Tagus Valley (Portugal), J. Seismol. 7, 431-447.

Cabral, J., P. Ribeiro, P. Figueiredo, N. Pimentel, and A. Martins (2004). The Azambuja fault: An active structure located in an intraplate basin with significant seismicity (Lower Tagus Valley, Portugal), J. Seismol. 8, 347-362.

Carrilho, F., J. C. Nunes, J. Pena, and M. L. Senos (2004). Catálogo Sísmico de Portugal Continental e Região Adjacente para o período 19702000, Report, Ministério da Ciéncia, Inovação e Ensino Superior Instituto de Meteorologia Divisão de Sismologia, Lisbon, Portugal, ISBN: 972-9083-12-6, Depósito legal No: 221 955/05.

Carvalho, J., J. Cabral, R. Gonçalves, L. Torres, and L. Mendes-Victor (2006). Geophysical methods applied to fault characterization and earthquake potential assessment in the Lower Tagus Valley, Portugal, Tectonophysics 418, 277-297.

Carvalho, J., T. Rabeh, M. Bielik, E. Szalaiova, L. Torres, M. Silva, F. Carrilho, L. Matias, and J. M. Miranda (2011). Geophysical study of the Ota-V.F. Xira-Lisbon-Sesimbra fault zone and the Lower Tagus Cenozoic basin, J. Geophys. Eng. 8, 395-411.

Carvalho, J., T. Rabeh, F. Carrilho, J. Cabral, and M. Miranda (2008). Geophysical characterization of the Ota-Vila Franca de XiraLisbon-Sesimbra fault zone, Portugal, Geophys. J. Int. 174, 567-584.

Cornell, C. (1968). Engineering seismic risk analysis, Bull. Seismol. Soc. Am. 58, 1568-1606.

Cunha, T. A., L. M. Matias, P. Terrinha, A. M. Negredo, F. Rosas, R. M. S. Fernandes, and L. M. Pinheiro (2012). Neotectonics of the SW Iberia margin, Gulf of Cadiz and Alboran Sea: A reassessment including recent structural, seismic and geodetic data, Geophys. J. Int. 188, 850-872

Dias, R. P. (2001). Neotectónica da Região do Algarve, Ph.D. thesis, Fac. Ciências, Univ. Lisboa, 369 pp. (in Portuguese)
Electric Power Research Institute, U.S. Department of Energy, and U.S. Nuclear Regulatory Commission (EPRI/DOE/NRC) (2012). Central and Eastern United States Seismic Source Characterization for Nuclear Facilities, EPRI, Palo Alto, California, U.S. DOE, and U.S. NRC.

Fernandes, R. M. S., B. A. C. Ambrosius, R. Noomen, L. Bastos, M. J. R. Wortel, W. Spakman, and R. Govers (2003). The relative motion between Africa and Eurasia as derived from ITRF2000 and GPS data, Geophys. Res. Lett. 30, 1828.

Fonseca, J. F. B. D. (2005). The source of the Lisbon earthquake (letter), Science 308, 5-6.

Fonseca, J. F. B. D., and R. E. Long (1991). Seismotectonics of SW Iberia: A distributed plate margin? in Seismicity, Seismotectonics and Seismic Risk of the Ibero-Maghrebian Region, J. Mezcua and A. Udias (Editors), Instituto Geográfico Nacional Memoir, Vol. 8, 227-240.

Fonseca, J. F. B. D., and S. P. Vilanova (2010). The April 231909 Benavente (Portugal) M 6.3 earthquake, Seismol. Res. Lett. 81, 534-536.

Frankel, A. (1995). Mapping seismic hazard in the central and eastern U.S., Seismol. Res. Lett. 66, 8-21.

Frankel, A., C. Mueller, T. Barnhard, D. Perkins, E. V. Leyendecker, N. Dickman, S. Hanson, and M. Hopper (1996). National Seismic Hazard Maps: Documentation, U.S. Geol. Surv. Open-File Rept. 96-532.

Fukao, Y. (1973). Thrust faulting at a lithospheric plate boundary: The Portugal earthquake of 1969, Earth Planet. Sci. Lett. 18, 205-216.

García-Mayordomo, J. (2005). Caracterización y análisis de la peligrosidad sísmica en el sureste de España, Ph.D. thesis, Universidad Complutense de Madrid, España, 379 pp. (in Spanish)

García-Mayordomo, J., E. Faccioli, and R. Paolucci (2004). Comparative study of the seismic hazard assessments in European National Seismic Codes, Bull. Earthq. Eng. 2, 51-73.

García-Mayordomo, J., J. M. Insua-Arévalo, J. J. Martínez-Díaz, A. JiménezDíaz, R. Martín-Banda, S. Martín-Alfageme, J. A. Álvarez-Gómez, M. Rodríguez-Peces, R. Pérez-López, M. A. Rodríguez-Pascua, E. Masana, H. Perea, F. Martín-González, J. Giner-Robles, E. S. Nemser, J. Cabral, and the QAFI Compilers Working Group (2012). The Quaternary active faults database of Iberia (QAFI v.2.0), J. Iberian Geol. 38, 285-302.

García-Mayordomo, J., J. M. Insua-Arévalo, J. J. Martínez-Díaz, H. Perea, J. A. Álvarez-Gómez, F. Martín-González, A. González, P. Lafuente, R. Pérez-López, M. A. Rodríguez-Pascua, J. Giner-Robles, J. M. Azañón, E. Masana, and X. Moreno (2010). Modelo integral de zonas sismogénicas de España, in Contribución de la Geología al Análisis de la Peligrosidad Sísmica, Insua-Arévalo y Martín-González (Editors), Sigüenza (Guadalajara, España), 193-196 (in Spanish).

Geissler, W. H., L. Matias, D. Stich, F. Carrilho, W. Jokat, S. Monna, A. IbenBrahim, F. Mancilla, M.-A. Gutscher, V. Sallarés, and N. Zitellini (2010). Focal mechanisms for sub-crustal earthquakes in the Gulf of Cádiz from a dense OBS deployment, Geophys. Res. Lett. 37, L18309, 309.

González-Fernández, A., D. Córdoba, L. Matias, and M. Torné (2001). Seismic crustal structure in the Gulf of Cadiz (SW Iberian Peninsula), Mar. Geophys. Res. 22, 207-223.

Grandin, R., J. F. Borges, M. Bezzeghoud, B. Caldeira, and F. Carrilho (2007). Simulations of strong ground motion in SW Iberia for the 1969 February $28\left(M_{\mathrm{s}}=8.0\right)$ and the 1755 November $1(\mathrm{M} \sim 8.5)$ earthquakes-II. Strong ground motion simulations, Geophys. J. Int. 171, 807-822.

Grünthal, G., and R. Wahlström (2012). The European-Mediterranean Earthquake Catalogue (EMEC) for the last millennium, J. Seismol. 16, 535-570.

Hanks, T. C., N. A. Abrahamson, D. M. Boore, K. J. Coppersmith, and N. E. Knepprath (2009). Implementation of the SSHAC Guidelines for Level 3 and 4 PSHAs-Experience gained from actual applications, U.S. Geol. Surv. Open-File Rept. 2009-1093.

Heidbach, O., M. Tingay, A. Barth, J. Reinecker, D. Kurfeß, and B. Müller (2008). The World Stress Map database release 2008, doi: 10.1594/ GFZ.WSM.Rel2008. 
Hiemer, S., D. D. Jackson, Q. Wang, Y. Y Kagan, J. Woessner, J. D. Zechar, and S. Wiemer (2013). A stochastic forecast of California earthquakes based on fault slip and smoothed seismicity, Bull. Seismol. Soc. Am. 103, 799-810.

Jiménez-Munt, I., M. Fernandez, M. Torne, and P. Bird (2001). The transition from linear to diffuse plate boundary in the Azores-Gibraltar region: Results from a thin-sheet model, Earth Planet. Sci. Lett. 192, 175-189.

Johnston, A. (1996a). Seismic moment assessment of earthquakes in stable continental regions-II. Historical seismicity, Geophys. J. Int. 125, 639-678.

Johnston, A. (1996b). Seismic moment assessment of earthquakes in stable continental regions-III. New Madrid 1811-1812, Charleston 1886 and Lisbon 1755, Geophys. J. Int. 126, 314-344.

Kafka, A. L. (2002). Statistical analysis of the hypothesis that seismicity delineates areas where future large earthquakes are likely to occur in the central and eastern United States, Seismol. Res. Lett. 73, 992-1003.

Kulkarni, R. B., R. R. Youngs, and K. J. Coppersmith (1984). Assessment of confidence intervals for results of seismic hazard analysis, in Proc. of the Eighth World Conference on Earthquake Engineering, San Francisco, California, 21-28 July 1984, Vol. 1, 263-270.

Lopes, F. C., P. Proença Cunha, and B. Le Gall (2006). Cenozoic seismic stratigraphy and tectonic evolution of the Algarve margin (offshore Portugal, southwestern Iberian Peninsula), Mar. Geol. 231, 1-36.

Lourenço, N., J. M. Miranda, J. F. Luis, A. Ribeiro, L. Mendes Victor, J. Madeira, and D. Needham (1998). Morpho-tectonic analysis of the Azores volcanic plateau from a new bathymetric compilation of the area, Mar. Geophys. Res. 20, 141-156.

Martínez Solares, J. M., and A. López Arroyo (2004). The great historical 1755 earthquake, effects and damage in Spain, J. Seismol. 8, 275-294.

Martínez Solares, J. M., and J. Mezcua (2002). Catálogo Sísmico de la Península Ibérica (800 a.c.-1900), Instituto Geográfico Nacional, Vol. 18 (in Spanish).

Musson, R. M. W., and S. L. Sargeant (2007). Eurocode 8 seismic hazard zoning maps for the UK, Br. Geol. Surv. Rept. CR/07/125.

Nemser, E., R. Basili, V. Kastelic, J. García-Mayordomo, J. Cabral, J. F. B. D. Fonseca, J. J. Martínez-Díaz, S. Vilanova, and the 2010 Working Group on Iberian Seismogenic Sources (2012). Database of Iberian seismogenic sources parameterized for use in the SHARE European-scale seismic source model, in Proc. of the XV World Conference on Earthquake Engineering, Lisbon, Portugal, 24-28 September 2012, $10 \mathrm{pp}$.

Oliveira, T. (1992). Carta Geológica de Portugal, 1:500.000 (coord. T. Oliveira). Serviços Geológicos de Portugal (in Portuguese).

Perkins, D. (2001). Fuzzy sources, maximum likelihood, and the new methodology, in A Unified Approach to Probabilistic Risk Assessments for Earthquakes, Floods, Landslide and Volcanoes, U.S. Geol. Surv. Open-File Rept. 01-324.

Pinheiro, L. M., R. C. L. Wilson, R. P. Reis, R. B. Whitmarsh, and A. Ribeiro (1996). The western Iberia margin: A geophysical and geological over-view, in Proc. of the Ocean Drilling Program, Vol. 149, Texas A\&M University, Ocean Drilling Program, College Station, Texas.

Reasenberg, P. (1985). Second-order moment of central California seismicity, 1969-82, J. Geophys. Res. 90, 5479-5495.

Reiter, L. (1991). Earthquake Hazard Analysis: Issues and Insights, Columbia University Press, New York.

Ribeiro, A., M. Antunes, M. Ferreira, R. Rocha, A. Soares, G. Zbyszewski, F. Moitinho de Almeida, D. Carvalho, and J. Monteiro (1979). Introduction à la géologie génerale du Portugal, Serviços Geológicos de Portugal, Lisbon, Portugal.

Ribeiro, A., J. Cabral, R. Baptista, and L. Matias (1996). Stress pattern in Portugal mainland and the adjacent Atlantic region, West Iberia, Tectonics 15, no. 2, 641-659.
Rockwell, T., J. Fonseca, C. Madden, T. Dawson, L. A. Owen, S. Vilanova, and P. Figueiredo (2009). Paleoseismology of the Vilariça segment of the Manteigas-Bragança fault in northeastern Portugal, in Palaeoseismology: Historical and Prehistorical Records of Earthquake Ground Effects for Seismic Hazard Assessment, K. Reicherter, A. M. Michetti, and P. G. Silva (Editors), Geological Society of London Special Publication, 237-258.

Rovere, M., C. R. Ranero, R. Sartori, L. Torelli, and N. Zitellini (2004). Seismic images and magnetic signature of the Late Jurassic to Early Cretaceous Africa-Eurasia plate boundary off SW Iberia, Geophys. J. Int. 158, 554-568.

Schorlemmer, D., and J. Woessner (2008). Probability of detecting an earthquake, Bull. Seismol. Soc. Am. 98, 2103-2117.

Senior Seismic Hazard Analysis Committee (SSHAC) Budnitz, R. J., G. Apostolakis, D. M. Boore, L. S. Cluff, K. J. Coppersmith, C. A. Cornell, and P. A. Morris (1997). Recommendations for probabilistic seismic hazard analysis: Guidance on uncertainty and use of experts, Washington, D.C., U.S. Nuclear Regulatory Commission Report, NUREG/CR-6372.

Stepp, J. C. (1972). Analysis of completeness in the earthquake sample in the Puget Sound area and its effect on statistical estimates of seismic hazard, in Proc. of the International Conf. on Microzonation for Safer Construction Research and Applications, Seattle, Washington, 30 October-3 November 1972, Vol. 2, 1897-1910.

Stich, D., J. Batlló, R. Macià, P. Teves-Costa, and J. Morales (2005). Moment tensor inversion with single-component historical seismograms: The 1909 Benavente (Portugal) and Lambesc (France) earthquakes, Geophys. J. Int. 162, 850-858.

Stich, D., R. Martín, and J. Morales (2010). Moment tensor inversion for Iberia-Maghreb earthquakes 2005-2008, Tectonophysics 483, 390-398.

Stich, D., E. Serpellioni, F. L. Mancilla, and J. Morales (2006). Kinematics of the Iberia-Maghreb plate contact from seismic moment tensors and GPS observations, Tectonophysics 426, 295-317.

Stucchi, M., A. Rovida, A. A. Gomez Capera, P. Alexandre, T. Camelbeeck, M. B. Demircioglu, V. Kouskouna, P. Gasperini, R. M. W. Musson, M. Radulian, K. Sesetyan, S. Vilanova, D. Baumont, D. Faeh, W. Lenhardt, J. M. Martinez Solares, O. Scotti, M. Zivcic, P. Albini, J. Batllo, C. Papaioannou, R. Tatevossian, M.Locati, C. Meletti, D. Viganò, and D. Giardini (2012). The SHARE European Earthquake Catalogue (SHEEC) 1000-1899, J. Seismol. 17, 523-544, doi: 10.1007/s10950-012-9335-2.

Swafford, L., and S. Stein (2007). Limitations of the short earthquake record for seismicity and seismic hazard studies, in Continental Intraplate Earthquakes, S. Stein and S. Mazzotti (Editors), Special Paper, Vol. 425, Geological Society of America, Boulder, Colorado, 49-58.

Terrinha, P. (1998). Structural geology and tectonic evolution of the Algarve Basin, Ph.D. thesis, Imperial College, University of London, London, United Kingdom, 428 pp.

Teves-Costa,P., I. Rio, C. Marreiros, R. Ribeiro, and J.F. Borges(1999). Source parameters of old earthquakes: Semi-automatic digitalization of analog records and seismic moment assessment, Nat. Hazards 19, 205-220.

United States Nuclear Regulatory Commission (USNRC) (2012). Practical Implementation Guidelines for SSHAC Level 3 and 4 Hazard Studies, Washington, D.C., U.S. Nuclear Regulatory Commission Report, NUREG-2117.

Vilanova, S., and J. F. D. B. Fonseca (2004). Seismic hazard impact of the Lower Tagus Valley fault zone (SW Iberia), J. Seismol. 8, 331-345.

Vilanova, S., and J. F. B. D. Fonseca (2007). Probabilistic seismic-hazard assessment for Portugal, Bull. Seismol. Soc. Am. 97, 1702-1717.

Vilanova, S., C. Nunes, and J. Fonseca (2003). Lisbon 1755: A case of triggered onshore rupture? Bull. Seismol. Soc. Am. 93, 2056-2068.

Wiemer, S., M. García-Fernández, and J. P. Burg (2009). Development of a seismic source model for probabilistic seismic hazard assessment of nuclear power plant sites in Switzerland: The view from PEGASOS Expert Group 4 (EG1d), Swiss J. Geosci. 102, 189-209.

Wilson, R. C. L. (1975). Atlantic opening and Mesozoic continental margin basins of Iberia, Earth. Planet. Sci. Lett. 25, 33-43. 
Wong, I. G., and S. S. Olig (1998). Seismic hazards in the Basin and Range Province: Perspectives from probabilistic analyses, in Basin and Range Province Seismic Hazards Summit, Western States Seismic Policy Council, Proceedings Volume, W. R. Lund (Editor), Utah Geological Survey Miscellaneous Publication 98-02, 110-127.

Woo, G. (1996). Kernel estimation methods for seismic hazard area source modeling, Bull. Seismol. Soc. Am. 86, 353-362.

Zitellini, N., E. Gràcia, L. Matias, P. Terrinha, M. A. Abreu, G. DeAlteriis, J. P. Henriet, J. J. Dañobeitia, D. G. Masson, T. Mulder, R. Ramella, L. Somoza, and S. Diez (2009). The quest for the Africa-Eurasia plate boundary west of the Strait of Gibraltar, Earth Planet. Sci. Lett. 280, 13-50.

Centre for Natural Resources and the Environment (CERENA)

Instituto Superior Técnico (IST)

Universidade de Lisboa

Av. Rovisco Pais, 1

1049-001 Lisbon, Portugal

susana.vilanova@ist.utl.pt

(S.P.V., G.M.B.-O., R.P.D.)

Seismic Hazards Group

URS Corporation

1333 Broadway, Suite 800

Oakland, California 94612

eliza.nemser@urs.com

(E.S.N., I.W.)

Departamento de Física and Centro de Geofísica de Évora

Escola de Ciências e Tecnologia

Universidade de Évora

Rua Romão Ramalho, 59

7002-554 Évora, Portugal

(M.B., J.F.B.)

Faculdade de Ciências da Universidade de Lisboa

Departamento de Geologia/Instituto D. Luiz

Edifício C6, Campo Grande

1749-016 Lisbon, Portugal

(A.B.d.S., J.C., J.M.)

Laboratório Nacional de Energia e Geologia

Estrada da Portela, Bairro do Zambujal

Apartado 7586-Alfragide

2610-999 Amadora, Portugal

(J.C., R.P.D.)
Departamento de Ciências da Terra, IMAR-CMA

Universidade de Coimbra

Largo Marquês de Pombal

3000-272 Coimbra, Portugal

(P.P.C.)

Centro de Geofísica

Departamento de Ciências da Terra

Universidade de Coimbra, Santa Clara

3040-004 Coimbra, Portugal

(F.C.L.)

Departamento de Engenharia Civil Arquitectura e Georrecursos Instituto de Engenharia de Estruturas Território e Construção (ICIST) Instituto Superior Técnico (IST), Universidade de Lisboa

Av. Rovisco Pais, 1

1049-001 Lisbon, Portugal

(C.S.O.)

Barcelona Center for Subsurface Imaging (BCSI)

Department of Geosciences, ICM-CISC

Pg. Marítim de la Barceloneta, 37-49

08003 Barcelona, Spain

(H.P.)

Instituto Geológico y Minero de España

C/La Calera, 1 Tres Cantos

28760 Madrid, Spain

(J.G.-M.)

GFZ, German Research Center for Geosciences

Telegrafenberg

D-14473 Potsdam, Germany

(R.A.)

Physics Department and Centre for Natural Resources and the Environment (CERENA)

Instituto Superior Técnico (IST)

Universidade de Lisboa

Av. Rovisco Pais, 1

1049-001 Lisbon, Portugal

(J.F.B.D.F.)

Manuscript received 4 August 2013;

Published Online 3 June 2014 